University of Chicago Law School

Chicago Unbound

Journal Articles

Faculty Scholarship

2001

\title{
When Courts and Politics Collide: Mongolia's Constitutional Crisis
}

Tom Ginsburg

Gombosuren Ganzorig

Follow this and additional works at: https://chicagounbound.uchicago.edu/journal_articles

Part of the Law Commons

\section{Recommended Citation}

Tom Ginsburg \& Gombosuren Ganzorig, "When Courts and Politics Collide: Mongolia's Constitutional Crisis," 14 Columbia Journal of Asian Law 309 (2001).

This Article is brought to you for free and open access by the Faculty Scholarship at Chicago Unbound. It has been accepted for inclusion in Journal Articles by an authorized administrator of Chicago Unbound. For more information, please contact unbound@law.uchicago.edu. 


\title{
WHEN COURTS AND POLITICS \\ COLLIDE: MONGOLIA'S \\ CONSTITUTIONAL CRISIS
}

\author{
TOM GINSBURG * \\ GOMBOSUREN GANZORJG **
}

\section{INTRODUCTION}

Mongolia's political system has received well-deserved attention as one of the most successful examples of democratization in the Asian region. ${ }^{1}$ Since 1990, Mongolia has undergone peaceful constitutional change and has conducted several democratic elections. Human rights are wellrespected, the media is free and political competition exists. ${ }^{2}$ This is all the more remarkable given that constitutional democracy has developed "without prerequisites,"3 that is, without a previous history of democracy or social pluralism that is sometimes thought necessary for democracy to flourish.

During the early years of transition, Mongolia's Constitutional Court played an important role in facilitating democratic change. The court occasionally overturned parliamentary legislation while serving as a vehicle to protect human rights and the constitutional scheme. However, in recent years Mongolia's Constitutional Court has found itself at the center of a major controversy regarding the very structure of the political system. Through a series of decisions that has placed it at odds with the legislature, the Court has raised questions about its ability to play an appropriate role in a constitutional democracy. This article traces the origins of the current

School of Law.

Assistant Professor of Law, University of Illinois, Urbana-Champaign.

Former Judge, Supreme Court of Mongolia; Adjunct Professor, Texas Wesleyan University

1. See annual reports in ASIAN SURVEY (1991-97).

2. U.S. DEP'T OF STATE, MONGOLIA HUMAN RIGHTS REPORT 2000; Tom Ginsburg and G. Ganzorig, Constitutionalism and Human Rights in Mongolia, in MONGOLIA IN TRANSTION (OLE BRUUN AND OLE ODGAARD, EDS, 1996.)

3. Steven Fish, Mongolia: Democracy without Prerequisites, 9 J. Denoc. 127 (1998). 
problems with the Mongolian constitutional scheme and describes the Court's role in precipitating the political crisis.

\section{BACKGROUND: MONGOLIA'S TRANSFORMATION AND THE 1992 CONSTITUTION}

Mongolia is a landlocked country located between Russia and China. Beginning in the $12^{\text {th }}$ century, its tribes united and conquered the largest empire the world has ever known, but gradually the country came to be dominated by the Manchu empire that governed China. ${ }^{4}$ Until 1911, Mongolia was administered as part of the Chinese empire. With China convulsed in revolution and chaos for the next decade, Mongolia began to seek its independence and in 1921, established an independent republic with the help of the Soviet Union. For the next seven decades, Mongolia was dominated by Soviet influence although it always maintained its independent statehood. A single party, the Mongolian People's Revolutionary Party (the "MPRP"), controlled politics.

Following the collapse of the Berlin Wall in 1989, Mongolian students began to demand democratic reforms. The ruling MPRP agreed and a new period of democracy was introduced. 5 One of the most important tasks was constitutional reform, and a large drafting committee was established with representation from all political parties. After canvassing some one hundred foreign constitutions, the new Constitution was promulgated in early 1992.6 The Constitution featured a new unicameral parliament called the State Great Hural, a directly elected President, and a Constitutional Court with the power to strike legislation that was unconstitutional.

Mongolia's Constitutional Court is a nine-member body with three members appointed by each of the President, the State Great Hural, and the Supreme Court. Cases can be brought to the Court by certain designated governmental officials as well as by any member of the public who sends a petition alleging a violation of the constitution.' Petitions are initially considered by one member of the Court. ${ }^{8}$ If the member believes there is a constitutional violation, a three-member panel of the Court hears the case.

4. See generally ROBERT WORDEN AND ANDREA MARLES, MONGOLIA: A COUNTRY STUDY (1991).

5. See Tom Ginsburg, Between Russia and China: Political Reform in Mongolia, 35 ASIAN SURVEY 459 (1995).

6. Alan J.K. Sanders, Mongolia's New Constitution, 32 ASIAN SURVEY 42 (1992).

7. CONST. OF MONGOLIA, Art. 69.

8. Law on Constitutional Court, Art. 9(1) 
A decision on unconstitutionality is automatically forwarded to the State Great Hural that has the right to accept or reject the Court's decision. If the State Great Hural accepts the decision of the Court, the act in question is deemed unconstitutional. On the other hand, if the State Great Hural rejects the finding of unconstitutionality, the case is sent back to the Constitutional Court for consideration by the full court en banc. The full court's decision is final. ${ }^{9}$ This procedure of legislative approval of declarations of unconstitutionality, which has some parallels with the procedure of the Constitutional Tribunal in Poland until 1997, reflects residual socialist notions of parliamentary sovereignty, namely that parliament has a legitimate role in constitutional interpretation. The debates over institutional design in Mongolia, however, ultimately culminated in a system where the Court has the final say on constitutionality.

In the elections immediately following the new Constitution, the MPRP won an overwhelming victory and for the next four years controlled the government and State Great Hural. Parliamentary legislation was occasionally challenged before the Constitutional Court in minor cases, and the Court was willing to strike legislation. Furthermore, the State Great Hural became embroiled in a number of disputes with the first President, P. Ochirbat. The Constitutional Court had to resolve some of these disputes as well, and by and large mediated them in a manner that led to increased legitimacy of the Court. Mongolia's democratic system seemed to be deepening despite the political dominance of the former communist party. ${ }^{10}$

\section{THE 1996 ELECTION AND ITS AFTERMATH}

In the 1996 parliamentary elections, the National Democrat-Social Democrat coalition came to power for the first time. "Before a government could be formed, however, a member of the coalition petitioned the Court to prevent the coalition from filling the cabinet with members of the State Great Hural, relying on a provision in the Constitution that "members of parliament shall have no other employment."12 The issue turned on the type

9. Law on Constitutional Court Procedure, Art. 3(3).

10. See Tom Ginsburg, Between Fire and Ice: Mongolia in 1996, 37 ASLAN SURVEY 60 (1997); Deepening Democracy: Mongolia in 1997, 38 ASLAN SURVEY 64 (1998).

11. Id.

12. CONST. OF MONGOLIA, Art. 29. The question of this member's motivation in bringing the suit is puzzling. D. Lamjav was a senior member of the Social Democratic Party, and had bren a professor of R. Gonchigdorj, the Speaker of Parliament. At one time he was considered a potential presidential candidate for the Party, and was considered to be a person of great intellect, with the highest levels of integrity and devotion to the Constitution. Some observers suggested that he filed the petition when it became clear that he would not be offered a cabinet post, hoping that by 
of political system established by the 1992 Constitution. Was it a presidential system where the cabinet is unrelated to the parliament? Or a parliamentary system, wherein the government is formed by the leading parties in parliament?

The Court initially found that parliamentary deputies could not hold cabinet posts. This provoked the rancor of the democratic coalition and forced it to scrap its anticipated government lineup, requiring a scramble to find qualified persons to fill the cabinet. The coalition's leadership accused the Court of acting in a politically motivated fashion, and called for more "scientific" methods of constitutional interpretations, such as a detailed inquiry into the travaux prepartoires of the constitutional drafting committee. $^{13}$

The State Great Hural was controlled, for the first time, by the new parties, and they were given an opportunity to accept or reject the Court's judgment. They predictably rejected it, leading to a reconsideration of the case by the full panel of the Court. A second round of arguments was held. National Democratic Party lawyer and Member of Parliament (MP) B. Delgerma argued that the parliamentary model had been adopted as a reaction to the socialist "presidential" system and the over-concentration of power in the hands of a single individual. It would be anti-democratic to allow persons who had run and lost in elections for district-based constituencies to become Ministers. She further argued that, regardless of the intentions of the drafters, Mongolian democratic practice had already established the parliamentary character of the political system, since the MPRP had formed the government with members of parliament during the first post-constitutional election in 1992. Furthermore, as a practical matter, all the party leaders had been electoral candidates. Unlike the U.S. system, where there is a separation between party leadership and electoral candidates, Mongolian democratic practice after 1990 had required that

narrowing the competition to non-MPs he might be more likely to secure a post. Such a motivation would have failed to anticipate the tremendous anger directed at Lamjav by his own party after the Court decision, which was seen to undermine the coalition's historic transition to power. Others suggested that Lamjav's motives were to benefit the coalition by forcing it to distribute power more broadly. A third possibility is that Lamjav saw himself as a strict constructionist, and simply believed that the Constitution required the separation of parliament and government. This is Lamjav's own claim about his motivation. In this view, he brought the case in an effort to enhance the separation of powers concept in the Mongolian constitutional structure, and to uphold the internal consistency of constitutional provisions. One question left outstanding by this account, however, is why he waited to file his petition until immediately after the election, when he had been aware that the previous MPRP government was also violating the provision by having MPs in cabinet positions. Lamjav did divulge in an interview with one of the authors that he had noticed the constitutional issue a year before bringing the claim.

13. Interview with senior member of the coalition, Ulaanbaatar, December 5, 1997. 
party leaders stand as candidates.

The Court was unconvinced by this position. After a second round of deliberations, the Court issued a decision upholding its earlier judgment to the effect that MPs could not join the cabinet without resigning their seats. ${ }^{14}$ The decision has had profound affects on subsequent politics. The decision was made after the nomination and approval of Prime Minister $M$. Enkhsaikhan, who had been Chairman of the coalition and leader of the successful election campaign. Enkhsaikhan had not run in the parliamentary election. In the immediate aftermath of the Court's decision, the coalition had to decide whether other leaders who had won parliamentary seats would resign them to take ministerial posts. The coalition had fifty out of seventysix parliamentary seats, while the MPRP held twenty-five. One seat was held by the United Traditional Party, whose representative aligned himself with the MPRP in the immediate post-election period. This configuration put the coalition in a difficult position: should fourteen MPs resign to take ministerial positions, the coalition majority would become thirty-six to twenty-five with the fourteen seats of parliament to be filled by elections. ${ }^{15}$ There was a real risk that the coalition would lose its historic majority.$^{16}$ In any case, even a single-seat loss to the MPRP would further jeopardize the ability of the coalition to obtain a quorum of two-thirds of the parliamentary membership: as it was, they were one seat short, and the swing voter from the United Traditional Party had helped the MPRP deny a quorum by joining a walkout during hearings to appoint the Vice-Speaker of the Hural. In light of these considerations, the coalition decided to comply with the decision and to form the government exclusively with non-MPs.

The insulation of the government from parliament certainly weakened democratic accountability. Neither the chief executive nor any member of his cabinet had won an election. This strange result seems antidemocratic. The usual principal-agent problems that exist between parliament and government in a parliamentary system were exacerbated by the lack of mechanisms for the parliament to discipline the government, and by the social and institutional distance created when cabinet members are not legislators. There was no opportunity for day-to-day policy debate, with the Prime Minister defending his policies before the public. Rather, government members had to be summoned to the parliament, and appear there as outsiders on an infrequent and extraordinary basis.

14. Judgment of the Constitutional Court (on file with authors).

15. Parliament had not yet clarified what would happen if a member vacated a seat.

16. The coalition subsequently reorganized the goverument to reduce the number of ministries to nine. If only nine MPs resigned, even if the MPRP won all the seats contested in by-elections, the coalition majority would be assured. 
In the aftermath of the decision, the democratic coalition found itself in the odd position of having its most powerful leaders ineligible for ministerial posts. With the coalition forced to give ministerial positions to second-line leaders, many top leaders were left as mere MPs. Without distributing ministerships, de facto power within the coalition could not match formal structure. Factional problems ensued, and the democratic coalition's term in government came to be widely viewed as a failed opportunity.

In summary, there were several tensions in the political system that were either directly caused or exacerbated by the decision to separate the parliament and government. These include the structural tension between parliament and government, latent political tensions within the coalition leadership itself, as top leaders were left without formal positions to match their power, and tensions within each party as leaders lost the ability to discipline backbenchers, leading to a rise in district-based political entrepreneurship on the part of MPs.

In early 1998, the State Great Hural passed a bill to allow Members of Parliament to serve in the Cabinet. The coalition then decided to replace the Enkhsaikhan government with a new one formed out of the parliament, led by former journalist Ts. Elbegdorj. The government, however, was weak, and fell within three months, initiating an eight month period of caretaker government, resolved only in December 1998 with the appointment of J. Narantsaltsralt as the new Prime Minister. Meanwhile, the new legislation was challenged, and the Constitutional Court duly followed its original decision in holding the act unconstitutional under article 29 , section 1 of the Constitution. ${ }^{17}$ Although this judgment was rejected by the State Great Hural, the full bench of the Court subsequently upheld the original decision. Again, the result was political chaos, with the MPRP demanding the resignation from parliament of cabinet members, and the democratic coalition speculating about early elections. ${ }^{18}$

\section{MONGOLIA'S FIRST CONSTITUTIONAL AMENDMENT}

With ordinary legislative channels precluded as a means of repairing the political system, parliamentarians turned to a constitutional amendment. Mongolia's first-ever constitutional amendment was passed by the State Great Hural in December 1999 with the support of all major political parties.

17. Constitutional Court Ruling, BBC, December 2, 1998, available in NEXIS, NEWS Library, ALLNWS file.

18. Id. 
The amendments sought to resolve the issue by providing that ministers could serve concurrently as MPs.

The complete text of the Constitutional amendment is reproduced here:

1. In case of a failure to appoint a new Prime Minister within $\mathbf{4 5}$ days, the Parliament should dissolve itself or the President shall dissolve it.

2. The Speaker and Deputy-Speaker of Parliament shall be nominated from among Parliament members and the voting shall be open. In the vote for the Deputy-Speaker each party group or coalition shall vote as a group.

3. The duration of the Parliament Session shall be not longer than $\mathbf{5 0}$ working days.

4. The quorum of the regular meeting of Parliament is a majority of members.

5. A Member of Parliament can serve as the Prime Minister or as a member of the Government.

6. Nomination of a candidate for the Prime Minister's position must be raised by the President for the Parliament's consideration within five days of the election.

7. The Prime Minister should reach an accord with the President, on the Government's composition, within a week, and in case of failure to reach consensus, the Prime Minister can raise the issue for parliamentary consideration. ${ }^{19}$

The amendment was sent to the President for signature. The President, however, promptly vetoed the amendment on December 24, 1999, even though it had the support of his own MPRP party members. ${ }^{20}$ Among the grounds given by the President for his veto was the lack of consultation with the Constitutional Court, which is alleged to have a role in constitutional amendments. This argument was based on article 68 section 1 of the Constitution, which provides, inter alia, that the Constitutional Court can propose constitutional amendments. The President also suggested the State Great Hural should have consulted with the 17 political parties not represented in it, along with the President, the National Security Council and the Government, before passing the amendment.

This tortured interpretation of the Constitution relied on a reading of the power to propose an amendment as including a right to consultation

19. Teriin medeelel \#59 (Government reporter), Ulaanbaatar, December 24, 1999 (translation by authors).

20. The veto was in accordance with the article 33 section 1.1 of the Const. of Mongolia, which states that the President has the right to veto, partially, or wholly, laws and other decisions adopted by the State Great Hural. 
or any proposed amendments. Explaining his veto in his speech on Constitution Day, President Bagabandi said:

Just like any other law, the Constitution cannot remain without amendments. However, an amendment must be made in accordance with the provisions of the Constitution and its tradition. The only criteria for the rule of law is whether we treat the Constitution in accordance with the principle provided by the Constitution. A law, particularly the Constitution, should not be applied in a discretionary fashion, nor should there be an attempt for a willful interpretation. This principle must have an important place in the government policy. Any amendment to the Constitution must express all the Mongolian peoples' wish and their opinion; therefore it must start from the people. I swore to the Constitution and to people, as the President of Mongolia, and I have the right and responsibility to save the original Constitution; therefore I express my real commitment for following this principle. ${ }^{21}$

It was also alleged that by allowing parliament members to serve in government, the amendment violated the separation of powers principle provided in the Constitution. The President criticized other parts of the amendment as well. He alleged that by reducing the quorum required to hold a parliamentary session the amendment disturbed the legislative process. Other alleged defects were the provision that the president could dissolve the parliament should it fail to nominate a prime minister within a certain period and the specification that party membership is a requirement for deputy speaker.

The President's veto, however, was overridden by an overwhelming majority at the State Great Hural on January 6, 2000. Only one member, J. Gombojav, voted to uphold the veto, saying that the draft of the First Amendment was presented to members of the State Great Hural on the morning of the day of discussion, not a week before its debate as required by the Parliamentary Rules. On this narrow procedural ground, he supported the President, but the rest of the Hural members voted to maintain the amendment as originally passed.

The rejection of the veto prompted an appeal by S. Narangerel, head of the Mongolia National University Law School, to the Constitutional Court on the validity of the amendments on procedural grounds. ${ }^{22}$ Narangerel argued that Article 69, section 1 provides that an amendment to

21. Translation by authors.

22. See ODRIIN SONIN newspaper (Ulaanbaatar), January 4, 2000. 
the Constitution must be adopted by a vote of not less than three-fourths of all members of the Parliament. ${ }^{23}$ According to the Constitution there must be 76 members of Parliament, but at the time of the session former member R. Amarjargal had been appointed Prime Minister, member O. Dashbalbar had passed away, and three members had been convicted and sentenced on corruption charges. Therefore, according to this argument, the Constitution could not be amended until all seats were filled. On March 15, the initial bench of the Court ruled that the amendments were themselves incompatible with the Constitution, particularly the separation of powers principle. Again, the Court had put the issue back into the hands of the State Great Hural.

According to the procedural law of the Constitutional Court, it was up to the Hural to accept or reject the Court decision within 15 days after it received the opinion. The Hural, however, chose to take no action at all. Without a rejection by the Hural, the Court could not hear the case again and issue a final decision en banc. This state of limbo was precisely what the Hural desired. On April 5, 2000 a group of lawyers sent a letter to the State Great Hural urging the members to accept the ruling of the Constitutional Court on the First Amendment, and demanding that they follow the law and public opinion. Professionals, politicians, and citizens were awaiting action by the Hural regarding the First Amendment. Despite the public criticism and three formal requests by the Constitutional Court, the Hural delayed its consideration.

Many different factors caused this late response. The democratic coalition that dominated the State Great Hural was rather busy with the upcoming elections and preferred to pass the problem to its successors. Furthermore, with elections upcoming, the political situation did not favor a debate over the First Amendment. Members of the State Great Hural simply did not want to take responsibility for any potential wrongdoing, or risk taking steps that might hurt their reputations right before the new election. Had the State Great Hural rejected the Court decision, the Constitutional Court would likely have overturned the First Amendment in a final decision en banc.

Elections in July led to an overwhelming victory by the MPRP, which took 72 out of 76 seats. In the first Session of the State Great Hural meeting, the MPRP majority agreed to ignore the Constitutional Court ruling and allow the formation of a government that included members of the Hural, as if the controversial amendments to the Constitution had survived. The Court had stood firm in its insistence on a separation of parliament and government, and as a consequence had provoked the

23. Id. 
politicians to ignore it. Many criticized the State Great Hural for engaging in its own constitutional interpretation, saying in effect that this violated the separation of powers principle because that function was reserved to the Constitutional Court.

On July 28, 2000, four months and 12 days after the Court's decision and nearly four months after the expiration of the period required by law for consideration of such a decision, the State Great Hural finally debated the Constitutional Court ruling, but avoided a formal rejection. By a vote of 62 to 2 , it stated that the Constitutional Court had heard an issue outside its jurisdiction-namely the constitutionality of a constitutional amendment. State Great Hural member Sanjaasurengiin Oyun, leader of the Civil Courage Party, opposed the State Great Hural's action, stating: "The Parliament is acting illegally. The problem is that they are trying to bend the constitution according to their problems. This is dangerous-they could raise their hands for fascism and then say it was constitutional."24 Other party leaders also expressed their concern about the State Great Hural's action. Mr. B. Jargalsaihan, Chairman of the Mongolian Republican Party, said that the chairman of the ruling party could be appointed as the Prime Minister, but not in a fashion that violated the law. Mr. U. Hurelbaatar, the Chairman of the Mongolian United Traditional Party, stated that the Constitution or decisions of the Constitutional Court could be violated further, if this practice became a regular occurrence.

The public reaction did not focus on the delay of over four months by the State Great Hural in reacting to the Court decision, but rather on the manner in which the Hural expressed its views. Instead of issuing a formal resolution reacting to the Court decision as required by the Law on the Parliament, the legislature decided to include a short note in its record indicating that it considered the issue finalized. The Constitutional Court expressed its dissatisfaction with the protocol, and on August 1,2000 it sent a letter demanding an official resolution. The Court also asserted that the State Great Hural had authorized itself to interpret the Constitution, which should be the exclusive job of the Constitutional Court.

The same day, Speaker of the Hural L. Enebish replied to the Constitutional Court Chairman, stating that the Parliament had concluded that any resolution accepting or rejecting the Court's decision would be considered an acceptance of the illegal action of the Constitutional Court. ${ }^{25}$

24. Irja Halasz, Parliament's Conclusion on the Constitutional Court Ruling, MONGOLlaN NEWS (Ulaanbaatar), July 29, 2000.

25. See Parliament Speaker Sent Reply Note to Constitutional Court Chairman, OANAMONTSAME, August 3, 2000. Montsame, the Mongolian National News Agency, is available at $<$ http://www.mol.mn/montsame/>. 
Other key members also expressed their view in favor of the State Great Hural decision. According to Mr. Ts. Sharavdorj, an influential lawyer and Member of the Hural, the Constitutional Court itself violated the Constitution by considering the First Amendment. The amendment was not an ordinary law, but rather became an organic part of the Constitution once the State Great Hural adopted the amendment by supermajority. The Court was not authorized to discuss whether the amendment was unconstitutional or not, much less overturn it. Sharavdorj suggested merging the Constitutional Court with the Supreme Court, asking rhetorically whether Mongolia needed two high Courts. ${ }^{26}$ Moreover, he mentioned the possibility of recalling those members of the Constitutional Court that had been appointed by the State Great Hural, despite the fact that there is no such formal mechanism of recall. These remarks could be seen as a tacit threat to the Court.

Sharavdorj's argument is that there is no jurisdiction for the Constitutional Court to consider the constitutionality of a constitutional amendment because of the supermajority required to pass an amendment. Once a supermajority acts, he seems to say, the Amendment becomes part of the Constitution, and the only job of the Court is to interpret it and apply it to any disputes that so require. This does not seem to be fully convincing: would it also prevent the Constitutional Court from examining the procedural question of whether the Amendment was adopted according to the formal procedures required by the Constitution? The answer is unclear from Sharavdorj's statement. Furthermore there is no jurisdictional limitation in the Constitution allowing the Court to consider only matters adopted by parliamentary majority. The Constitution is also silent on the question of whether amendments need be introduced only after consultation with other bodies and the Constitutional Court as the President's veto suggested.

In any case, to determine whether such provisions exist in the Constitution itself requires interpretation of the document. In this regard, the Court certainly has a role and arguably should have the final determination. The Court ought to have what the German Constitutional Court has called the Kompetenz Kompetenz, the power to determine what the Constitution dictates its jurisdiction to include. ${ }^{27}$

The Hural's response to the Court decision, neither accepting nor rejecting it, itself raises a constitutional question on the status of the Court

26. See ZUUNY MEDEE newspaper, March 28, 2000.

27. See generally DONALD KOMAIERS, CONSTITUTIONAL JURISPRUDENCE OF THE FEDERAL REPUBLIC OF GERMANY (2d. ed. 1996). 
decision. Most observers agree that the Court must review the State Great Hural response, whatever its form. In this regard, Mr. Namhai Haidav, who filed the initial petition to the Court, re-petitioned again, complaining that the Court unduly delayed hearing his petition. ${ }^{28}$ In a newspaper interview, Constitutional Court Chairman N. Jantsan said that the State Great Hural violated the Constitution by refusing to render a formal resolution, since the Hural had intended to prevent the Constitutional Court from hearing the issue. ${ }^{29}$ There should not be any confusion about whether the issue was under the jurisdiction of the Constitutional Court, said Jantsan, and only the Court is capable of determining the extent of Constitutional Court jurisdiction. Therefore the Court must review the matter and issue a final decision. Otherwise, the Hural would never render any formal resolution if it disagreed with a Constitutional Court ruling, allowing Parliament to avoid the supervision of the Constitutional Court.

On the question of why it delayed its own re-consideration of the question by the Full Bench, Chairman Jantsan responded that the Court was waiting to see whether the State Great Hural would render a decision according to the law. He also noted that the Court did not want to destabilize the political situation in the country. However, he concluded that delay was no longer justified. On October 29, 2000, the Court reconsidered the Constitutional Amendment and again ruled that it was unconstitutional. It relied on procedural grounds, specifically Article 68.1, which states that amendments to the Constitution may be initiated by certain designated bodies. The Court read these as being exclusive, implying that a Constitutional Amendment initiated by State Great Hural on its own was not constitutional because the legislature failed to consult with the Constitutional Court and the President. Seven members of the Court were present and voted.

The MPRP Government was now in a dilemma. The Prime Minister and four members of the cabinet were themselves members of the State Great Hural. Giving up the parliamentary seats would force a by-election, but that was not completely out of the question given the huge MPRP majority. Nevertheless, the MPRP responded by initiating another Constitutional amendment with exactly the same text as had already been adopted-and rejected - the previous year. The proposed amendment was presented simultaneously to the State Great Hural, the President and Constitutional Court, seeking to avoid the charge that the initiators had not followed proper procedures. In a sense, they were challenging the

28. ODRIN SONIN newspaper (Ulaanbaatar), October 16, 2000.

29. See Interview, DAll Y MIRROR, November 16, 2000. 
Constitutional Court to review the amendment on substantive grounds since the Court had, in its final rejection, relied on procedural grounds rather than the provision in the Constitution that says that members can have no other employment outside Parliament.

The amendment passed by a vote of 68-0 with four members protesting the session by not attending. Again, however, the President vetoed the amendment, forcing the State Great Hural to reconsider the amendment. There is little doubt that the Hural will be able to muster the necessary two-thirds votes since the amendment itself had required a threequarters vote. There also seems little doubt that the issue will again come before the Constitutional Court, since the original question has still not been answered as to whether Article 29(1), which states that members of Parliament can have no other employment except as provided by law, allows members to also serve in the government.

\section{ANALYSIS}

The story of the Mongolian Constitutional Court and its game of political hot potato with the President and Parliament illustrates the dangers for courts in new democracies when they cannot avoid overtly political issues. Although the Court had several opportunities to defuse the situation by giving in to parliamentary wishes, it never took the opportunity to do so and in this manner has extended the constitutional crisis for over four years. The crisis concerns the fundamental nature of the political system and is not likely to be easily resolved.

Our view is that the Court was correct in determining its ability to hear the validity of constitutional amendments, at least on procedural grounds. Otherwise, Parliament would be able to pass unconstitutional amendments without any review whatsoever. On the other hand there are no substantive limitations in the Mongolian Constitution on the ability of Parliament to pass constitutional amendments. Furthermore, the particular grounds of the final Court decision rejecting the amendments seem difficult to defend. Article 68(1) states that "Amendments to the Constitution may be initiated by organization and officials enjoying the right to legislative initiative and may be proposed by the Constitutional Court to the National Parliament." But this does not mean that the Hural itself cannot pass constitutional amendments on its own initiative or that there is any requirement of consultation before passing an amendment. Indeed, it is clear that Parliament itself enjoys the legislative initiative so can "initiate" amendments under Article 68(1). The contrary reading seems to give the Constitutional Court the exclusive right of "proposing" amendments to the 
parliament, which is an odd function to give to the Court whose primary role is interpreting the constitutional text. A more democratic theory of constitutional amendment would seek to locate the power of initiation in the Parliament itself.

If the Parliament should have the right to initiate amendments, even without consultation, it also seems clear that the Court should have the power to consider the constitutionality of amendments. Comparative experience shows that sometimes constitutional courts have considered the validity of amendments, beyond merely ensuring that the amendment process followed constitutionally-required procedures. The South African Constitutional Court, for example, struck provisions of the draft Constitution itself during that country's transition to democracy. ${ }^{30}$ In another well-known case, the Indian Supreme Court struck down parts of a constitutional amendment that precluded judicial review of property rights claims. ${ }^{31}$ The Parliament had passed the amendment in part because it was unhappy with the Court's property rights jurisprudence, as the Court had continually required the government to pay full compensation for property that it nationalized. The Court held that constitutional amendments inconsistent with the Constitution's "basic structure" could be rejected by the Court. Because the right to appeal to the Court for violations of fundamental rights was explicitly granted in the Constitution, an amendment voiding it was not acceptable.

It is important to note that in the aftermath of the decision, Indira Gandhi's government attacked the Court as an institution, announcing publicly that it intended to limit Court appointments to those sympathetic to government concerns and bypassing the usual seniority norm concerning appointments to the Chief Justiceship. ${ }^{32}$ When Gandhi declared emergency rule in 1975, the legislature passed a constitutional amendment preventing the Court from scrutinizing future constitutional amendments for conformity with the Constitution. In the face of these attacks on jurisdiction and threats to judicial independence, the Court largely submitted to politicians' desires. Nevertheless, it has insisted on and retained the power to review amendments.

The Indian case can be distinguished from the present case in part because the former involved an issue of basic human rights. Although the discussion in the Indian Constitutional Court focused on "basic structure,"

30. HeInZ KLUG, CONSTITUTING Democracy (2000); Richard SPITZ and Matthew CHASKALON, THE POLITICS OF TRANSITION (2000).

31. Kesavananda Bharati v. State of Kerala, AIR 1973 SC 1461.

32. See Charles EpP, The Rights Revolution (1998). 
the case involved a government seeking to overturn the fundamental bargain on property rights that had been made at the founding of the country. The Mongolian case involves a real issue of "basic structure," namely the character of the political system. The constitutional amendment was passed because of a dysfunction in the design of basic political institutions. Arguably, the Court should defer to the political process in such areas because it is politicians, not the Court, who are in the best position to evaluate the efficacy of political structure. ${ }^{33}$ From this perspective, Mongolian constitutional democracy would have been better served had the Court recognized that the political process was responding to a need for a more effective system of governance. The fact that the amendment was supported by all major political forces is some evidence of this need.

It is also important to note that the constitutional amendment was passed to overturn a decision of the Court itself. United States experience shows that constitutional amendments are frequently proposed to overturn Supreme Court decisions. In the aftermath of Roe $v$. Wade, ${ }^{34}$ which upheld the right of a woman to have an abortion, numerous constitutional amendments have been proposed to ban abortion entirely. At least seven constitutional amendments were passed in order to reverse a Supreme Court decision. For example, the Thirteenth Amendment (1865) barring slavery and the Fifteenth Amendment (1868) protecting the citizenship of African Americans effectively overturned Dred Scott v. Sandford. ${ }^{35}$ The Sixteenth Amendment (1913) gave Congress the power to impose an income tax, thereby overturning Pollock v. Farmers' Loan and Trust $\mathrm{Co}^{36}$ The TwentySixth Amendment (1971) overturned Oregon v. Mitchell ${ }^{37}$ which, among other things, held that Congress could not regulate the voting age in state elections. The amendment set the voting age at 18 years.

In none of these cases was the Court given an opportunity to strike the amendment as unconstitutional, and it is unlikely the Court would be viewed as having the power to do so. In part this is because the amendment process in the United States requires a long period of time. Article V of the United States Constitution provides that a constitutional amendment may be proposed by a two-thirds vote of the House of Representatives and the Senate or by a national convention called by Congress at the request of twothirds of the state legislatures. In practice, all of the amendments have been proposed by either the House or Senate. After proposal, the amendment

33. JESSE CHOPER, THE SUPREME COURT AND THE POLMICAL PROCESS (1983).

34. 410 U.S. 113 (1973).

35. 60 U.S. 393 (1856).

36. 158 U.S. 601 (1S95).

37. 400 U.S. 112 (1970). 
must be ratified by three-fourths of the state legislatures (38 states) or special conventions called in three-fourths of the states. The Twenty-First Amendment was the only one to be ratified in the latter manner. Congress decides which method of ratification will be used and the time limit within which it must take place. Thus the procedures are complex and it is noteworthy that only twenty-seven amendments have been passed since the Constitution was ratified in 1789 , ten of them having been passed simultaneously in the form of the 1791 Bill of Rights.

Other countries have simpler procedures for passing constitutional amendments. ${ }^{38}$ Usually, when a legislature is involved, it must pass the amendment by a supermajority, as in the Mongolian case. In other countries, such as Israel, a simple majority can pass an amendment, blurring the distinction between amendments and ordinary legislation. In some instances, the legislature must pass the amendment and then send it before the people for approval in a referendum. This is the case in such countries as Australia, Japan and Switzerland. It is generally true that the more government institutions that must be involved and the more complex the procedure, the more difficult it is to pass amendments. 39

It is also important to recognize that there is more to the Constitution than meets the eye. Many changes in the American governmental structure have occurred without formal constitutional amendment. ${ }^{40}$ For example, the United States Constitution is silent on the issue of political parties, but they are fundamental to the working of modern government and arguably have some "constitutional" status in the political system. The entire administrative state is not contemplated in the text of the Constitution itself. ${ }^{41}$ The practice of government can become constitutional in importance. Arguably, the Mongolian Constitutional Court could have taken this view of political structure and found that it need not rule on the main issue presented before it, as to do so would unnecessarily disrupt the political system.

In terms of the underlying issue as to whether members of the State Great Hural can serve in the government, it is arguable that the Constitution does not require that government and Parliament be separated as the Court

38. See generally Donald Lutz, Toward a Theory of Constitutional Amendment, in RESPONDING TO IMPERFECTION: THE THEORY AND PRACTICE OF CONSTITUTIONAL AMENDMENT 237-74 (S. Levinson, ed., 1995).

39. Id.

40. See Sanford Levinson, How Many Times has the Constitution been Amended? in RESPONDING TO IMPERFECTION: THE THEORY AND PRACTICE OF CONSTITUTIONAL AMENDMENT 15 (S. Levinson, ed., 1995).

41. See Edward Rubin, Getting Past Democracy, 149 U. PENN. L. REv. 711 (2001). 
suggests. Many other political systems allow members of parliament to serve in the government. The drafters of the Mongolian Constitution failed to make clear that their intent was a complete separation of cabinet and Parliament. The June 1991 draft of the Constitution contained a provision, Article 32, stating that "Members of the State Great Hural cannot concurrently occupy the posts of ... members of the government. ${ }^{2 / 2}$ But this text was explicitly rejected in the final version in favor of the Article 29 text stating that members may not hold posts "other than those assigned by law." The founders thus considered and rejected a complete separation between the two powers. Attributing rationality to the drafters and engaging in the always-risky business of determining legislative intent, it appears that Mongolia's constitutional founders intended to allow MPs to join the government, but subject to ordinary legislation defining the terms under which they may do so. In the absence of such legislation, the Court was faced with an interpretive problem, namely whether to read the original text literally, or to rely on more purposive strategies of constitutional interpretation. The Court took the former route, but the latter may have been more appropriate. ${ }^{43}$ This is particularly true given that the Court had earlier rejected legislation proposing to facilitate MPs serving in govemment. Undoubtedly, the Court could have avoided the entire crisis by simply allowing that legislation to stand.

If the amendment itself seems to have been constitutional, the State Great Hural's failure to respond to the Court decision finding otherwise was not contemplated by the drafters and appears to have hurt the constitutional order. At a minimum, the Hural violated its own organic law by failing to consider the issue within fifteen days and then issuing a ruling either accepting or rejecting the Constitutional Court decision. The legal requirement is that the State Great Hural must render the resolution only on whether it agrees or disagrees with the ruling of Constitutional Court, but the law did not authorize the Hural to consider whether the Court ruling is itself legal or illegal. The approach of the Hural was to take for itself the power to interpret whether the Court's behavior was constitutional, a problematic approach with great potential for deadlock and dueling interpretations. Our view is that the Hural and the Constitutional Court must both act with greater restraint and demonstrate their commitment to the rule of law by abiding by the requirements of the Constitution, while also respecting each other's institutional compliance.

42. Draft on file with authors.

43. See PHILIP BOBBI, CONSTITUTIONAL FARE: THEORY OF THE CONSTITUTION (1982) for a discussion of different modes of constitutional interpretation. 
In short, neither Parliament nor the Court has come out of the crisis unscathed and both have engaged in short-sighted behavior. Ever-hungry for ministerships, the members of Parliament have ignored the long-term stability and health of the political system. In the face of such behavior, the Court has tried to stand firm but may have hurt its own legitimacy through its own bizarre readings of the constitutional text.

Mongolia's transition to democracy since 1990 has been stronger and more successful than any other central Asian state. But it remains the case that the internal constitutional order has been damaged by the continuous state of uncertainty regarding the basic norms of the political system since the first suit brought in 1996 on the issue of separating the Parliament and government. The Constitutional Court has several times passed up opportunities to resolve this issue in a way that allows for a functioning political system; instead it has consistently adopted an overly strict reading of the constitutional text without sensitivity to political dynamics. The political forces, on the other hand, have disregarded the Constitutional Court's pronouncements and have endangered the constitutional order themselves. Mongolia's political and legal community must seek a reasonable resolution to the issue as soon as possible. Otherwise this fragile experiment of growing democracy in foreign soil may fail. 